\title{
Evaluation of the Modified Systemic Inflammation Score and Inflammatory Markers According to Stage in Colorectal Cancer
}

\section{Kolon Kanserinde Evreye Göre Modifiye Sistemik Enflamasyon Skoru ve Enflamatuvar Belirteçlerin Değerlendirilmesi}

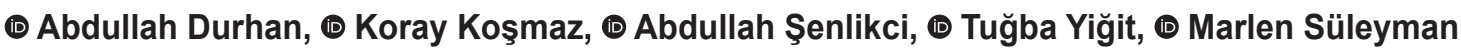 \\ Ankara Training and Research Hospital, Clinic of General Surgery, Ankara, Turkey
}

\section{HIIIIIII ABSTRACT}

Aim: There is recent increasing evidence of an association between inflammation and cancer. There are many studies showing that inflammatory markers can be used as prognostic markers in many types of cancer. The aim of this study was to retrospectively evaluate the effect of tumour stage on inflammatory markers and the modified systemic inflammation score (mSIS).

Method: The study included 218 of 376 patients identified as having undergone curative surgery in Ankara Training and Research Hospital general surgery clinic with the diagnosis of colorectal cancer (CRC) between February 2015 and February 2020. A retrospective evaluation was made of clinical and pathological data, including age, gender, tumor type, histological tumour grade, localization of the tumor, lymph node involvement, hemogram results, albumin, carcinoembryonic antigen, and carbohydrate antigen 19-9 (CA-19-9). Laboratory data of neutrophil-to-lymphocyte ratio (NLR), platelet-to-lymphocyte ratio (PLR), lymphocyte-to-monocyte ratio (LMR)and mSIS were analyzed according to the tumor-node-metastasis stage.

Results: When the cases were evaluated in terms of stage, there was a statistically significant difference in terms of Hb, albumin, neutrophil and platelet value $(\mathrm{p}<0.05)$. When the cases were evaluated in terms of NLR, PLR and mSIS, there was a statistically significant difference between stage I and stage II $(\mathrm{p}<0.05)$.

Conclusion: NLR, PLR and mSIS may be predictive factors that can be used to differentiate stage 1 from other stages. Determining the pre-treatment levels of NLR, PLR and mSIS can provide useful information in early diagnosis or the evaluation of treatment options in CRC patients.

Keywords: Colorectal cancer, mSIS, NLR, PLR, stage

\section{|IIIIIII| ÖZ}

Amaç: Enflamasyon ve kanser arasındaki ilişki uzun zamandır gündemde olan konulardan biridir. Enflamatuvar belirteçlerin birçok kanser türünde prognostik belirteç olarak kullanılabileceğini gösteren çok sayıda çalışma mevcuttur. Bu çalışmada enflamatuvar belirteçler ve modifiye enflamatuvar sistemik skorunun (mSIS) tümör evresine etkisini retrospektif olarak değerlendirmeyi amaçladık.

Yöntem: Şubat 2015 ile Şubat 2020 arasında Ankara Eğitim ve Araştırma Hastanesi Genel Cerrahi Kliniği’ne başvuran ve kolorektal kanser (KK) tanısı ile küratif cerrahi yapılan 376 hastanın 218'i çalışmaya dahil edildi. Olgular yaş, cinsiyet, tümör tipi, tümörün histolojik derecesi, tümörün lokalizasyonu, lenf nodu tutulumu, tam kan sonuçları, albumin, karsinoembriyojenik antijen, karbonhidrat antijeni 19-9 (CA 19-9) gibi klinikopatolojik verilerine veri sistemi üzerinden retrospektif olarak ulaşıldı. Nötrofil lenfosit oranı (NLR), trombosit lenfosit oranı (PLR), lenfosit monosit oranı ve mSIS laboratuvar verileri tümör-nod-metastaz evresine göre analiz edildi.

Bulgular: Olgular evre açısından değerlendirildiğinde hemoglobin, albümin, nötrofil ve trombosit değerleri açısından istatistiksel olarak anlamlı farklılık vardı $(\mathrm{p}<0,05)$. Olgular NLR, PLR ve mSIS açısından değerlendirildiğinde ise evre 1 ile evre 2 arasında istatistiksel olarak anlamlı fark vardı $(\mathrm{p}<0,05)$.

Sonuç: NLR, PLR ve mSIS, evre l’i diğer evrelerden ayırt etmek için kullanılabilecek öngörücü faktörler olabilir. NLR, PLR ve mSIS'nin tedavi öncesi düzeylerinin belirlenmesi, KK hastalarında erken tanı veya tedavi seçeneklerinin değerlendirilmesinde faydalı bilgiler sağlayabilir.

Anahtar Kelimeler: Kolorektal kanser, mSIS, NLR, PLR, evre

Address for Correspondence/Yazışma Adresi: Abdullah Şenlikci, MD,

Ankara Training and Research Hospital, Clinic of General Surgery, Ankara, Turkey

E-mail: asenlikci94@hotmail.com ORCID ID: orcid.org/0000-0002-4321-4004

Received/Geliş Tarihi: 08.06.2020 Accepted/Kabul Tarihi: 09.07.2020

${ }^{\circ}$ Copyright 2021 by Turkish Society of Colon and Rectal Surgery

Turkish Journal of Colorectal Disease published by Galenos Publishing House. 


\section{Introduction}

Colorectal cancers (CRCs) are one of the most commonly observed cancers, with morbidity and mortality rates placing it as the third most common cancer worldwide in $2018 .^{1}$ The relationship between inflammation and cancer was discovered by Rudolf Virchow for the first time in the $19^{\text {th }}$ century. There is abundant evidence that the neutrophil-tolymphocyte ratio (NLR) can be used as a prognostic factor in many cancer types from studies conducted to predict postoperative survival and classify patients before surgery. ${ }^{2}$ Cancer progression and metastasis are considered to be increased by systemic inflammation. ${ }^{3}$ NLR and platelet-tolymphocyte ratio (PLR) have recently been used in studies to identify systemic inflammation. ${ }^{4,5}$

This study aimed to retrospectively evaluate the effect of tumour stage on inflammatory markers and modified systemic inflammation score (mSIS).

\section{Materials and Methods}

Patients who underwent curative surgery in Ankara Training and Research Hospital General Surgery Clinic and had a diagnosis of CRC between February 2015 and February 2020 were identified. Patients were excluded from the study for various reasons, including (1) perforation or obstruction, (2) known inflammatory disease (rheumatoid arthritis, ankylosing spondylitis, etc.), (3) recurrent tumour, (4) other known malignancies and (5) incomplete data. We included patients who had a neoadjuvant or complementary treatment for their disease. A retrospective examination of the clinicopathological data of the remaining 218 patients was made, including age, gender, tumour type, histological tumour grade, localisation of the tumour, lymph node involvement, haemogram results, albumin, carcinoembryonic antigen (CEA) and CA19-9. All blood samples were taken a week before the surgery. The NLR, PLR and lymphocyte-to-monocyte ratio (LMR) were calculated using the simple proportioning method in the electronic system.

mSIS is a scoring system based on serum albumin and LMR. The patients are categorised as 0 points with albumin value $\geq 4.0 \mathrm{~g} / \mathrm{dL}$, one point with albumin $<4.0 \mathrm{~g} / \mathrm{dL}$ and $\mathrm{LMR} \geq 3.4$ and two points with albumin $<4.0 \mathrm{~g} / \mathrm{dL}$ and $\mathrm{LMR}<3.4 .^{5}$

Tumour staging was applied according to the tumour, node and metastasis (TNM) staging system approved by AJCC $8^{\text {th }}$ edition, published in 2018.

\section{Statistical Analysis}

Data were analysed using SPSS version 21.0 software. Values showing a parametric distribution were expressed as mean \pm standard deviation, and variables not showing a normal distribution were expressed as median and interquartile range values. In the comparisons of groups of multiple data, ANOVA was used to determine whether there was a significant difference. A value of $\mathrm{p}<0.05$ was considered statistically significant.

\section{Results}

\section{Clinical and Pathological Features of Patients}

A total of 376 patients were included in the study: 158 patients were excluded and 218 patients were included. The study included 137 (62.8\%) males and 81 (37.2\%) females with a mean age of 23.91 years (range: $23-91$ years). In 81 (37.1\%) patients, the primary tumour was located in the right colon, in 42 (19.2\%) patients, the left colon, in 34 (15.5\%) patients, the sigmoid colon and in $52(23.8 \%)$ patients, the rectum. Nine cases $(4.1 \%)$ had synchronous tumours in the right and left colon. According to histological grade, $62(28.4 \%)$ lesions were well differentiated, 92 (42.2\%) were moderately differentiated and $61(27.9 \%)$ were poorly differentiated (Table 1). No significant difference was determined between the cancer stages regarding age, gender, tumour localisation and histological type (adenocarcinoma, mucinous adenocarcinoma, stone ring cell carcinoma, etc.).

\section{Tumour and Inflammatory Markers}

The study results showed that NLR, which is one of the inflammatory markers, was statistically significantly higher in stage II $(3.6 \pm 1.7)$ than in stage I $(2.5 \pm 1.5)$ cancers $(\mathrm{p}=0.037)$. PLR was found to be statistically significantly higher in stage II $(213.1 \pm 97.8)$ than in stage I $(159.8 \pm 69.9)$ cancers $(\mathrm{p}=0.004)$ (Figure 1$)$. Neutrophil and platelet counts were significantly higher in stage II than in stage I ( $p=0.003 ; p=0.009$, respectively). No statistically significant difference was determined between the groups in terms of lymphocyte, monocyte and red cell distribution width (Rdw) values $(p>0.05)$. There was no statistically significant difference between the groups in terms of LMR (Table 1).

According to the mSIS, two points were scored by $26.8 \%$ of stage I tumours and by $59.4 \%$ of stage II tumours, and the difference was determined to be statistically significant $(\mathrm{p}=0.012)$ (Table 2) (Figure 2). The CEA and CA 19-9 values were higher in patients at stage 4 than in the other groups, but the difference was not statistically significant.

A statistically significant difference was determined between stage I and stage II cancers in terms of haemoglobin, albumin, neutrophil, platelet, NLR, PLR and mSIS values $(\mathrm{p}=0.001, \mathrm{p}=0.01, \mathrm{p}=0.003, \mathrm{p}=0.009, \mathrm{p}=0.004, \mathrm{p}=0.037$ and $\mathrm{p}=0.012$, respectively) (Table 3 ). Neutrophil, platelet, NLR, PLR, and mSIS values were higher in stage II than stage I, and haemoglobin and albumin values were lower in stage II than stage I. 
Table 1. Clinical and pathological features of cases

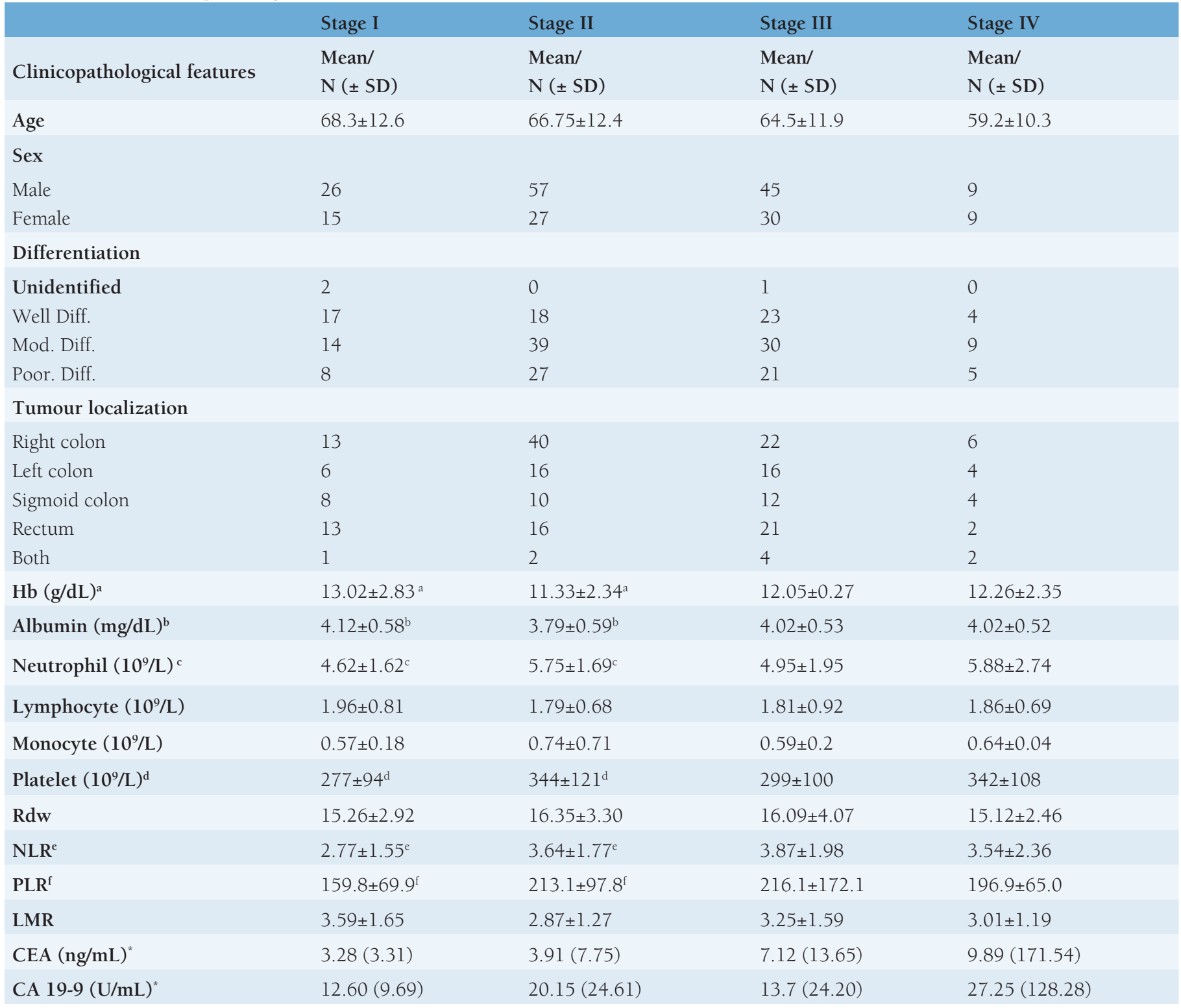

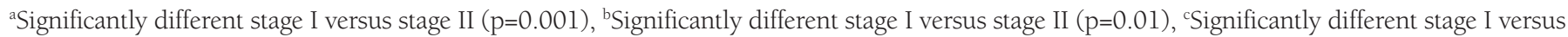
stage II ( $p=0.003)$, dSignificantly different stage I versus stage II ( $p=0.009)$, ${ }^{e}$ Significantly different stage I versus stage II ( $\left.p=0.037\right)$, Significantly different stage I versus stage II ( $\mathrm{p}=0.004)$.

"Variables not showing normal distribution were stated as median and interquartile range (IQR) values

Hb: Hemoglobin, Rdw: Red cell distribution width, NLR: Neutrophil-to-lymphocyte ratio, PLR: Platelet-to-lymphocyte ratio, LMR: Lymphocyte-tomonocyte ratio, CEA: Carcinoembryonic antigen, CA: Carbohydrate antigen

Table 2. Modified inflamatory systemic score (mSIS) of the cases

\begin{tabular}{llll} 
Stage & MSIS & & \\
I & Albumin $\geq 4.0$ (score 0) & Albumin <4.0; LMR $\geq 3.4$ (score 1) & Albumin <4.0; LMR <3.4 (score 2) \\
II & $26(63.4 \%)$ & $4(9.75 \%)$ & $11(26.8 \%)^{x}$ \\
III & $30(40.5 \%)$ & $10(13.5 \%)$ & $44(59.4 \%)^{x}$ \\
IV & $44(58.6 \%)$ & $12(16 \%)$ & $19(25.3 \%)$ \\
\hline
\end{tabular}

xStage I vs stage II sig. diff. ( $\mathrm{p}=0.012)$, MSIS: Modified systemic inflammation score, LMR: Lymphocyte-to-monocyte ratio 

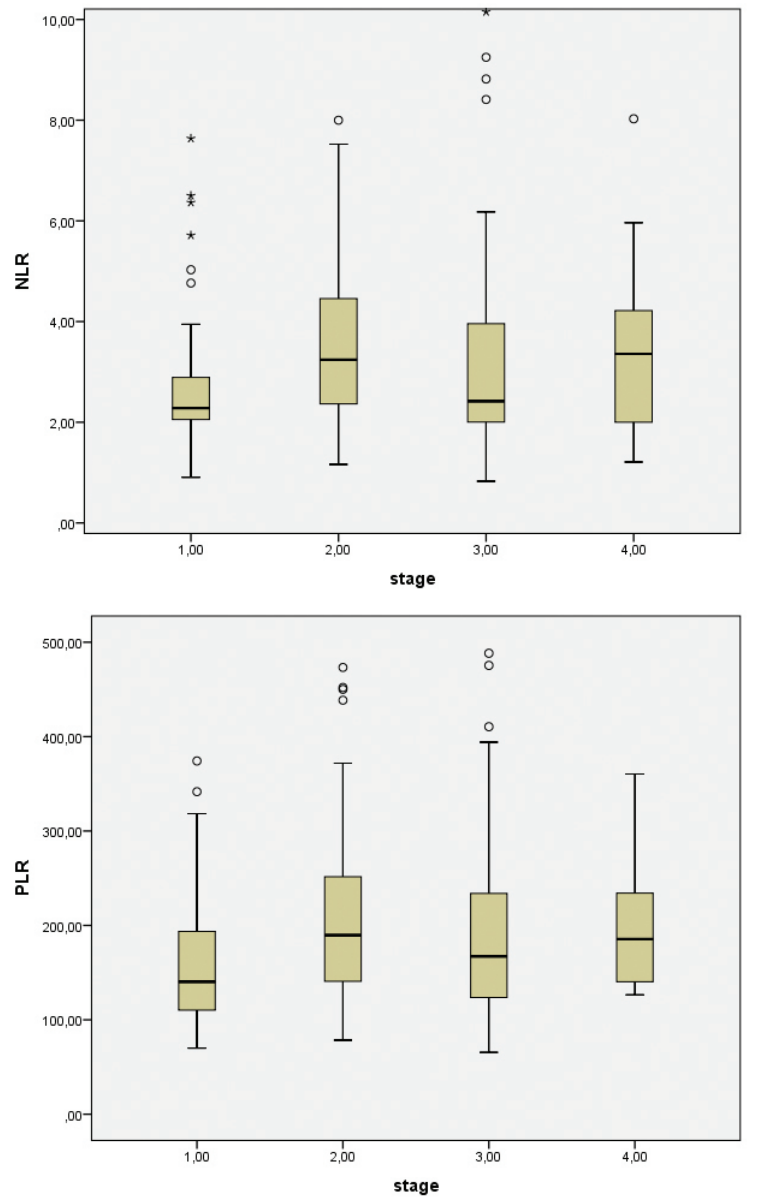

Figure 1. Distribution of NLR (A) and PLR (B) by TNM staging system NLR: Neutrophil-to-lymphocyte ratio, PLR: Platelet-to-lymphocyte ratio

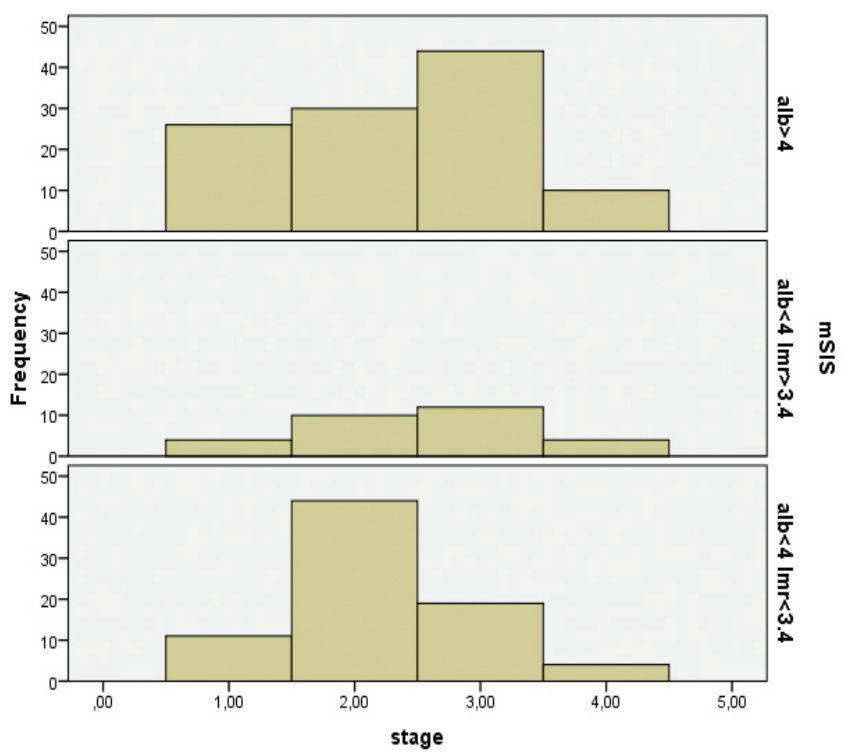

Figure 2. Distribution of modified inflammatory systemic scoring system according to TNM staging system

\section{Discussion}

Many definitions are related to the association between elevated NLR and poor oncological outcomes. ${ }^{6}$ According to a study by Ding et al. ${ }^{7}$, the host response to the tumour is lymphocyte-dependent. Although tumour infiltrating lymphocytes in the primary tumour are initially an indicator of good prognosis, increased neutrophils later increase the potent proangiogenic factors that cause the tumour to develop and progress. Therefore, NLR is the balance between protumour inflammatory status and antitumour immune status. ${ }^{6}$ Rashtak et al. ${ }^{8}$ stated that NLR is an important marker of prognosis in colon cancer, and Galizia et al. ${ }^{9}$ also showed that preoperative NLR is an important predictor showing the probability of recurrence. Guo et al. ${ }^{10}$ stated that the right and left colon cancers are different from each other, and while NLR can be considered a predictive factor in the right colon cancer, it cannot be a predictive factor in the left colon cancer. In this study, it was concluded that NLR was higher in stage II than in stage I. This result shows that the low NLR in early stages before surgery may also contribute to patient's treatment plan.

Platelets facilitate the proliferation of tumours by detaching the tumour from its primary site and masking the tumour cells from immune surveillance. Platelets also help metastasis, thus causing distant metastasis. When the number of platelets in patients with colon cancer was examined, a relationship was found between the primary tumour and high platelet count. ${ }^{11} \mathrm{Li}$ et al. ${ }^{12}$ demonstrated that PLR is a predictive factor indicating the prognosis in colon cancer and concluded that as PLR increases, patient's survival decreases. Hu et al. ${ }^{13}$ showed that PLR can be used to differentiate benign colon tumours from malignant colon tumours. In this study, it was determined that PLR was higher in stage II than stage I. Accordingly, PLR value may play an important role in patient's treatment plan, plateletdependent drug selection, and evaluation of the response to treatment.

A low lymphocyte count is considered to cause a weak and inadequate immunological reaction to the tumour. Tumour infiltrating leukocytes, including neutrophils and monocytes, play an important role in tumour development and progression. ${ }^{14}$ Ozawa et al. ${ }^{15}$ showed that LMR is a prognostic indicator in stage II colon cancer undergoing curative resection, and survival increases with increasing LMR. Peng et al. ${ }^{16}$ reported that LMR is a superior predictor in terms of survival compared with NLR and PLR in patients with colon cancer who have liver metastasis. In this study, no statistically significant difference was found when LMR was evaluated in terms of tumour stage. 
Table 3. Clinical and pathological features of stages I and II

\begin{tabular}{|c|c|c|c|}
\hline & $\begin{array}{l}\text { Stage I } \\
\text { Median/N }\end{array}$ & $\begin{array}{l}\text { Stage II } \\
\text { Median/N }\end{array}$ & $\mathrm{p}$ \\
\hline Age & $68.3 \pm 12.6$ & $66.75 \pm 12.4$ & 1 \\
\hline \multicolumn{4}{|l|}{ Sex } \\
\hline Male & 26 & 57 & \multirow{2}{*}{1} \\
\hline Female & 15 & 27 & \\
\hline \multicolumn{4}{|l|}{ Differentiation } \\
\hline Unidentified & 2 & 0 & \multirow{4}{*}{0.028} \\
\hline Well diff. & 17 & 18 & \\
\hline Mod. diff. & 14 & 39 & \\
\hline Poor diff & 8 & 27 & \\
\hline \multicolumn{4}{|l|}{ Tumour localisation } \\
\hline Right colon & 13 & 40 & \multirow{5}{*}{0.15} \\
\hline Left colon & 6 & 16 & \\
\hline Sigmoid colon & 8 & 10 & \\
\hline Rectum & 13 & 16 & \\
\hline Both & 1 & 2 & \\
\hline $\mathrm{Hb}(\mathrm{g} / \mathrm{dL})$ & $13.02 \pm 2.83^{\mathrm{a}}$ & $11.33 \pm 2.34^{\mathrm{a}}$ & 0.001 \\
\hline Albumin (mg/dL) & $4.12 \pm 0.58^{b}$ & $3.79 \pm 0.59^{b}$ & 0.01 \\
\hline Neutrophil $\left(10^{9} / \mathrm{L}\right)$ & $4.62 \pm 1.62^{c}$ & $5.75 \pm 1.69^{c}$ & 0.003 \\
\hline Lymphocyte $\left(10^{9} / \mathrm{L}\right)$ & $1.96 \pm 0.81$ & $1.79 \pm 0.68$ & 0.84 \\
\hline Monocyte $\left(10^{9} / \mathrm{L}\right)$ & $0.57 \pm 0.18$ & $0.74 \pm 0.71$ & 0.42 \\
\hline Platelet $\left(10^{9} / \mathrm{L}\right)$ & $277 \pm 94^{\mathrm{d}}$ & $344 \pm 121^{d}$ & 0.09 \\
\hline Rdw & $15.26 \pm 2.92$ & $16.35 \pm 3.30$ & 0.61 \\
\hline NLR & $2.77 \pm 1.55^{\mathrm{e}}$ & $3.64 \pm 1.77^{\mathrm{e}}$ & 0.037 \\
\hline PLR & $159.8 \pm 69.9^{f}$ & $213.1 \pm 97.8^{f}$ & 0.004 \\
\hline LMR & $3.59 \pm 1.65$ & $2.87 \pm 1.27$ & 0.063 \\
\hline CEA (ng/mL) & $3.28(3.31)$ & $3.91(7.75)$ & 0.40 \\
\hline CA 19-9 (U/mL) & $12.60(9.69)$ & $20.15(24.61)$ & 0.32 \\
\hline
\end{tabular}

Hb: Hemoglobin, Rdw: Red cell distribution width, NLR: Neutrophil-to-lymphocyte ratio, PLR: Platelet-to-lymphocyte ratio, LMR: Lymphocyte-tomonocyte ratio, CEA: Carcinoembryonic antigen, CA: Carbohydrate antigen

Systemic inflammation plays a critical role in cancer pathogenesis and progression. Increased C-reactive protein and low serum albumin levels are biomarkers of systemic inflammation. ${ }^{17}$ The systemic inflammation score is based on the preoperative serum albumin level, and LMR is a strong prognostic marker in clear-cell renal cell carcinoma. ${ }^{18}$ Lin et al. ${ }^{19}$ concluded that mSIS is a useful predictive factor for postoperative survival in stomach cancer. Suzuki et al. ${ }^{17}$ reported that SIS is a novel prognostic factor in patients with CRC and is an alternative inflammation-based biomarker, which may improve the prediction of clinical outcomes. According to the hypothesis of Mariani et al. ${ }^{20}$, inflammatory reactions play an important role in the early stages of CRC development. Similarly, in this study, there was a significant difference in mSIS between stages I and II. Although LMR was not significant when evaluated according to stage alone, it was significant when used with albumin in mSIS. According to our study, the mSIS value can also be used in treatment planning and evaluation of response to treatment.

\section{Study Limitations}

This study has some limitations. First, it was a retrospective study in a single centre, and the statistical power was decreased due to the small number of stage IV patients compared with other stages. 


\section{Conclusion}

In conclusion, the results of this study showed that NLR, PLR and mSIS may be predictive factors that can be used to differentiate stage I CRC from stage II. Determining the pretreatment levels of NLR, PLR and mSIS can provide useful information in early diagnosis or evaluation of treatment options in patients with CRC.

\section{Ethics}

Ethics Committee Approval: Ethics committee approval was obtained on 17.09.2020 as the study numbered 364 .

Informed Consent: Retrospective study.

Peer-review: Externally peer reviewed.

\section{Authorship Contributions}

Surgical and Medical Practices: A.D., K.K., M.S., Concept: A.D., K.K., Design: A.D., A.S.., T.Y., Data Collection or Processing: K.K., A.Ş., T.Y., Analysis or Interpretation: A.D., T.Y., M.S., Literature Search: A.D., T.Y., M.S., Writing: A.D., A.S.

Conflict of Interest: No conflict of interest was declared by the authors.

Financial Disclosure: The authors declared that this study received no financial support.

\section{References}

1. Siegel RL, Miller KD, Jemal A. Cancer statistics, 2018. CA Cancer J Clin 2018;68:7-30.

2. Balde AI, Fang S, He L, Cai Z, Han S, Wang W, Li Z, Kang L. Propensity score analysis of recurrence for neutrophil-to-lymphocyte ratio in colorectal cancer. J Surg Res 2017;219:244-252.

3. Abe T, Amano H, Kobayashi T, Hanada K, Nakahara M, Ohdan H, Noriyuki T. Preoperative neutrophil-to-lymphocyte ratio as a prognosticator in early stage pancreatic ductal adenocarcinoma. Eur J Surg Oncol 2018;44:15731579 .

4. Templeton AJ, McNamara MG, Šeruga B, Vera-Badillo FE, Aneja P, Ocaña A, Leibowitz-Amit R, Sonpavde G, Knox JJ, Tran B, Tannock IF, Amir E. Prognostic role of neutrophil-to-lymphocyte ratio in solid tumors: a systematic review and meta-analysis. J Natl Cancer Inst 2014;106:djul24.

5. Templeton AJ, Ace O, McNamara MG, Al-Mubarak M, Vera-Badillo FE, Hermanns T, Seruga B, Ocaña A, Tannock IF, Amir E. Prognostic role of platelet to lymphocyte ratio in solid tumors: a systematic review and metaanalysis. Cancer Epidemiol Biomarkers Prev 2014;23:1204-1212.

6. Özgehan G, Kahramanca \$s, Kaya İO, Bilgen K, Bostancı H, Güzel H, Küçükpınar T, Kargıcı H. Neutrophil-lymphocyte ratio as a predictive factor for tumor staging in colorectal cancer. Turk J Med Sci 2014;44:365368
7. Ding PR, An X, Zhang RX, Fang YJ, Li LR, Chen G, Wu XJ, Lu ZH, Lin JZ, Kong LH, Wan DS, Pan ZZ. Elevated preoperative neutrophils to lymphocyte ratio predicts risk of recurrence following curative resection for stage IIA colon cancer. Int J Colorectal Dis 2010;12:1427-1433.

8. Rashtak S, Ruan X, Druliner BR, Liu H, Therneau T, Mouchli M, Boardman LA. Peripheral Neutrophil to Lymphocyte Ratio Improves Prognostication in Colon Cancer. Clin Colorectal Cancer 2017;16:115-123.e3.

9. Galizia G, Lieto E, Zamboli A, De Vita F, Castellano P, Romano C, Auricchio A, Cardella F, De Stefano L, Orditura M. Neutrophil to lymphocyte ratio is a strong predictor of tumor recurrence in early colon cancers: A propensity score-matched analysis. Surgery 2015;158:112-120.

10. Guo D, Li X, Xie A, Cao Q, Zhang J, Zhang F, Li W, Chen J. Differences in oncological outcomes and inflammatory biomarkers between rightsided and left-sided stage I-III colorectal adenocarcinoma. J Clin Lab Anal 2020;34:e23132.

11. Catal O, Ozer B, Sit M. Prediction of lymph node metastasis in colon cancer via platelet to lymphocyte ratio and platelet count. J Coll Physicians Surg Pak 2020;30:250-253

12. Li Z, Xu Z, Huang Y, Zhao R, Cui Y, Zhou Y, Wu X. Prognostic values of preoperative platelet-to-lymphocyte ratio, albumin and hemoglobin in patients with non-metastatic colon cancer. Cancer Manag Res 2019;11:3265-3274

13. Hu Z, Tan S, Chen S, Qin S, Chen H, Qin S, Huang Z, Zhou F, Qin X. Diagnostic value of hematological parameters platelet to lymphocyte ratio and hemoglobin to platelet ratio in patients with colon cancer. Clin Chim Acta 2020;501:48-52

14. Stotz M, Pichler M, Absenger G, Szkandera J, Arminger F, Schaberl-Moser R, Samonigg H,Stojakovic T, Gerger A. The preoperative lymphocyte to monocyte ratio predicts clinical outcome in patients with stage III colon cancer. Br J Cancer 2014;110:435-440

15. Ozawa T, Ishihara S, Kawai K, Kazama S, Yamaguchi H, Sunami E, Kitayama J, Watanabe T. Impact of a lymphocyte to monocyte ratio in stage IV colorectal cancer. J Surg Res 2015;199:386-392.

16. Peng J, Li H, Ou Q, Lin J, Wu X, Lu Z, Yuan Y, Wan D, Fang Y, Pan Z. Preoperative lymphocyte-to-monocyte ratio represents a superior predictor compared with neutrophil-to-lymphocyte and platelet-to-lymphocyte ratios for colorectal liver-only metastases survival. Onco Targets Ther 2017; 10:3789-3799.

17. Suzuki Y, Okabayashi K, Hasegawa H, Tsuruta M, Shigeta K, Kondo T, Kitagawa Y. Comparison of preoperative inflammation-based prognostic scores in patients with colorectal Cancer. Ann Surg 2018;267:527-531.

18. Chang Y, An H, Xu L, Zhu Y, Yang Y, Lin Z, Xu J. Systemic inflammation score predicts postoperative prognosis of patients with clear-cell renal cell carcinoma. Br J Cancer 2015;113:626-633.

19. Lin JX, Lin JP, Xie JW, Wang JB, Lu J, Chen QY, Cao LL, Lin M, Tu R, Zheng $\mathrm{CH}$, Huang CM, Li P. Prognostic importance of the preoperative modified systemic inflammation score for patients with gastric cancer Gastric Cancer 2019;22:403-412.

20. Mariani F, Sena P, Roncucci L. Inflammatory pathways in the early steps of colorectal cancer development. World J Gastroenterol 2014;20:97169731. 